\title{
PENGARUH TINGKAT ABSENSI DAN PERAN INSENTIF TERHADAP PRODUKTIVITAS KERJA KARYAWAN BAGIAN PRODUKSI PADA PT DEKOR ASIA JAYAKARYA
}

\section{Rina Fitriana}

\begin{abstract}
ABSTRAK
Penelitian ini bertujuan untuk mengetahui dan menganalisis produktivitas kerja karyawan bagian produksi pada PT Dekor Asia Jayakarya. Sehubungan dengan hal tersebut bagaimana karyawan dapat bekerja dengan sebaik mungkin dan karyawan mempunyai motivasi yang tinggi dalam menyelesaikan pekerjaan dengan adanya pemberian insentif serta kedisiplinan yang tinggi berdasarkan tingkat absensi. Maka penelitian ini bertujuan untuk menunjukkan signifikasi pengaruh tingkat absensi dan insentif terhadap produktivitas kerja karyawan. Dalam menganalisa data digunakan analisis deskriptif, kemudian analisis regresi linier sederhana dan analisis regresi parsial menunjukkan bahwa variable Tingkat Absensi (X1) berpengaruh terhadap Produktivitas Kerja Karyawan pada PT. Dekor Asia Jayakarya dengan nilai probabilitas sebesar 0,015. Sedangkan variabel Insentif (X2) berpengaruh terhadap Produktivitas Kerja Karyawan pada PT. Dekor Asia Jayakarya dengan nilai probabilitas sebesar 0,008. Variabel Tingkat Absensi dan Insentif berpengaruh secara simultan terhadap Produktivitas Kerja Karyawan pada PT. Dekor Asia Jayakarya dengan koefisien determinasi sebesar 42,5\%. Berdasarkan hasil penelitian ini disimpulkan bahwa faktor Tingkat Absensi merupakan variabel yang paling dominan berpengaruh terhadap Produktivitas Kerja Karyawan pada PT. Dekor Asia Jayakarya.
\end{abstract}

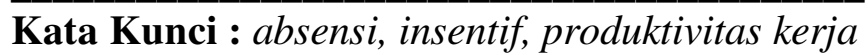




\section{PENDAHULUAN}

Menjelang era perdagangan bebas dapat menyebabkan iklim kompetisi yang tinggi di segala bidang. Kondisi tersebut memaksa setiap perusahaan harus dapat bekerja dengan lebih efisien, efektif, dan produktif. Tingkat kompetisi yang tinggi ini memacu tiap-tiap perusahaan untuk mempertahankan kelangsungan hidup organisasinya. Dengan demikian maka perusahaan dapat terus berjalan dan memenuhi kebutuhan para anggota organisasi dan kebutuhan konsumen.

Dalam organisasi hendaklah seorang pemimpin menyadari kebutuhan pegawai yang bersangkutan, dimana organisasi memberikan imbalan atau jasa pegawai yang telah diberikan untuk kemajuan organisasi, imbalan tersebut merupakan rangsangan yang telah memberikan motivasi agar memiliki prestasi dan kinerja yang baik.

Insentif adalah penghargaan atau ganjaran yang diberikan untuk memotivasi para pegawai agar produktivitasnya tinggi dan sifatnya tidak tetap atau sewaktu-waktu. Imbalan yang dapat memberikan motivasi tersebut biasa disebut dengan insentif. Pada dasarnya pemberian insentif bukanlah hak tetapi penghormatan terhadap pegawai yang telah menunjukan kemampuannya dan prestasi kerja yang baik dalam melaksanakan tugasnya hal ini dimaksudkan untuk memotivasi kerja.

Produktivitas suatu organisasi dipengaruhi oleh banyak faktor, antara lain gaji dan insentif yang layak dan adil serta kinerja yang baik.

Untuk mengetahui kinerja karyawan maka perlu dilakukan penilaian kinerja. Penilaian kinerja individu sangat bermanfaat bagi dinamika pertumbuhan organisasi secara keseluruhan. Melalui penilaian tersebut maka dapat diketahui kondisi sebenarnya tentang bagaimana kinerja karyawan.

Pada akhirnya perusahaan diharapkan mampu menyusun suatu sistem absensi dan insentif yang baik, dimana sistem absensi ini dapat menunjukkan tingkat kedisiplinan para karyawan sehingga dapat dilakukan penilaian kinerja. Dari penilaian kinerja tersebut dapat mempengaruhi besar kecilnya insentif yang akan diberikan. Dengan begitu diharapkan perusahaan baru akan mampu memberikan insentif yang adil dan layak kepada karyawannya.

Adanya pola hubungan antara absensi dan insentif dalam meningkatkan produktivitas kerja karyawan maka penulis tertarik untuk melaksanakan penelitian dengan mengambil judul "Pengaruh Tingkat Absensi dan Insentif Terhadap Produktivitas Kerja Karyawan Bagian Produksi Pada PT Dekor Asia Jayakarya".

\section{TINJAUAN PUSTAKA}

\section{Tingkat Absensi}

Menurut Malayu Hasibuan (2008:84) Absensi karyawan merupakan salah satu tolak ukur metode pengembangan karyawan, jika absensi karyawan setelah mengikuti pengembangan menurun, maka metode pengembangan yang dilakukan baik, sebaliknya jika absensi karyawan tetap berarti pengembangan yang diterapkan kurang baik.

Semangat kerja dapat diukur melalui absensi/presensi pegawai ditempat kerja, tanggung jawabnya terhadap pekerjaan, disiplin kerja, kerja sama dengan pimpinan atau teman sejawat dalam organisasi serta tingkat produktivitas kerjanya. (Hasley, 1992;67).

Presensi merupakan kehadiran pegawai yang berkenaan dengan tugas dan kewajibannya. Pada umumnya instansi/lembaga selalu mengharapkan pegawainya untuk datang dan pulang tepat waktu, sehingga pekerjaan tidak tertunda. Ketidakhadiran seorang pegawai akan berpengaruh terhadap produktivitas kerja, sehingga instansi/lembaga tidak bisa mencapai tujuan secara optimal.

Dengan adanya tingkat absensi yang baik maka dapat meningkatkan disiplin pegawai. Sedangkan yang dimaksud dengan disiplin adalah suatu sikap, tingkah laku dan 
perbuatan yang sesuai dengan peraturan dari perusahan atau instansi baik tertulis maupun tidak (Nitisemito, 1982; 199).

\section{Insentif}

Istilah insentif pada umunya digunakan untuk menggambarkan rencana-rencana pembayaran upah yang dikaitkan secara langsung maupun tidak langsung dengan standart produktivitas kerja karyawan atau profitabilitas organisasi atau kedua kriteria tersebut. Para karyawan yang bekerja di bawah sistem insentif finansial berarti prestasi kerja karyawan menentukan secara langsung atau sebagian penghasilan mereka.

Rencana-rencana insentif bermaksud untuk menghubungkan keinginan karyawan akan pendapatan finansial tambahan dengan kebutuhan organisasi dan efisiensi produksi. Yang di maksud dengan insentif adalah sistem upah yang bertujuan untuk meningkatkan produktivitas kerja karyawan dan mempertahankan karyawan yang berprestasi untuk tetap dalam perusahaan.

Ada beberapa pengertian insentif seperti yang dikemukakan oleh Mathis dan Jackson (2002:165) "Insentif merupakan upaya untuk mengaitkan imbalan yang nyata yang diberikan kepada karyawan untuk kinerja yang melampaui harapan”. Dalam kaitannya dengan karyawan, menurut Sarwoto (1991:144): "Insentif merupakan sarana motivasi yang dapat diberikan secara sengaja kepada para pekerja agar dalam diri mereka timbul semangat yang lebih besar untuk berprestasi bagi organisasi”.

\section{Sedangkan Hariandja (2002:265)} memberikan pengertian insentif dengan mengatakan bahwa: "Insentif adalah bentuk pembayaran langsung yang didasarkan atau dikaitkan langsung dengan kinerja dan pembagian keuntungan bagi pegawai akibat peningkatan produktivitas atau pengehematan biaya. Insentif umumnya dilakukan sebagai strategi untuk meningkatkan produktivitas dan efisiensi perusahaan dengan memanfaatkan perilaku pegawai yang mempunyai kecenderungan kemungkinan besar bekerja seadanya atau tidak optimal".
Berdasarkan uraian di atas maka dapat disimpulkan bahwa insentif merupakan salah satu bentuk rangsangan atau motivasi yang sengaja diberikan kepada karyawan untuk mendorong semangat kerja karyawan agar mereka bekerja lebih produktif lagi, meningkatkan prestasinya dalam mencapai tujuan perusahaan.

\section{Produktivitas Kerja}

Pengertian produktivitas menurut Haryono Sudriamunawar (2006:66) yaitu: "Produktivitas mengandung sikap mental yang selalu mempunyai pandangan bahwa kehidupan hari ini harus lebih baik dari hari kemarin dan hari esok lebih baik dari hari ini. Secara umum produktivitas mengandung pengertian perbandingan antara hasil yang dicapai dengan keseluruhan sumber daya yang digunakan".

Menurut Sedarmayanti (2001:57) produktivitas adalah bagaimana menghasilkan atau meningkatkan hasil barang dan jasa setinggi mungkin dengan memanfaatkan sumber daya secara efisien.

Produktivitas sangat berkaitan dengan prestasi kerja karena dengan produktivitas yang tinggi berarti karyawan tersebut memiliki prestasi kerja yang tingi, perlu juga adanya kreatifitas yang maksudnya bahwa individu tersebut tidak malas, penuh imajinasi, inovatif dan penuh daya kreatif.

Secara umum produktivitas mengandung pengertian perbandingan hasil yang dicapai dengan keseluruhan sumber daya yang dipergunakan.Sehingga dapat dikemukakan bahwa produktivitas adalah ukuran efisiensi dengan mana modal, material, tehnologi, manajemen sumber daya manusia dan informasi yang digunakan dengan tujuan memproduksi barang dan jasa secara ekonomis. Sumber daya manusia memegang peranan utama dalam proses peningkatan produktivitas, karena peralatan produksi, tekhnologi serta system manajemen pada hakekatnya adalah hasil karya manusia.

Dari beberapa pendapat tersebut, dapat disimpulkan bahwa produktivitas kerja adalah 
kemampuan seseorang untuk menghasilkan barang atau jasa dengan menggunakan berbagai sumber produksi sesuai dengan mutu dan jangka waktu yang telah ditentukan oleh perusahaan.

\section{Hubungan antara Tingkat Absensi dan Insentif dengan Produktivitas Kerja}

Menguraikan tentang hubungan antara tingkat absensi dan insentif dengan produktivitas kerja, disini dapat digambarkan bahwa tingkat absensi dan insentif yang ada dalam perusahaan/organisasi itu sangat penting, karena tingkat absensi dan insentif merupakan salah satu faktor penentu berhasil tidaknya suatu organisasi dalam mencapai tujuan. Sebab apabila tingkat absensi dan insentif yang diterapkan dalam organisasi perusahaan tersebut tidak sesuai dengan situasi dan kondisi internal organisasi, seperti tingkat keahlian dan kematangan karyawannya maka akan berpengaruh terhadap perilaku karyawan dalam menjalankan tugas yang buruk sehingga produktivitasnya akan menurun. Karena antara tingkat absensi dan insentif yang diterapkan dengan tingkat keahlian dan kematangan dari karyawan tidak relevan dan sehingga efektivitas insentif yang diterapkan kurang memenuhi harapan. Pemberian insentif yang efektif merupakan usaha-usaha pihak perusahaan untuk dapat memberikan dorongan pada karyawan agar mencapai tingkat produktivitas yang diharapkan.

Tingkat absensi dan pemberian insentif sangat diperlukan oleh setiap organisasi/perusahaan untuk menjaga dan meningkatkan bentuk, semangat untuk mendapatkan tingkat produktivitas kerja yang diharapkan. Berdasarkan uraian tersebut di atas penulis dapat menyimpulkan bahwa setiap perusahaan harus mempunyai bentuk dan semangat dengan memberikan insentif sesuai dengan keadaan dan kondisi yang ada, karena akan memudahkan adanya hubungan serasi dan seimbang antara proses produksi dengan kemampuan dan kematangan dari karyawan sehingga usaha untuk meningkatkan produktivitas kerja karyawan sesuai dengan yang diharapkan.

\section{METODOLOGI PENELITIAN}

Penelitian ini dilaksanakan di PT Dekor Asia Jayakarya yang beralamat di Karangnongko RT 10 Panggungharjo, Sewon, Bantul.

Metode penelitian ini menggunakan deskriptif dan eksplanatori atau penelitian penjelasan (explanatory research), karena memberikan gambaran tentang variable penelitian dan menjelaskan pengaruh yang terjadi antara variable-variabel penelitian dan kemudian menguji hipotesis yang telah dirumuskan sebelumnya.

Dijelaskan oleh Singarimbun dan Effendi (1995:5), apabila untuk data yang sama, peneliti menjelaskan hubungan kausal antara variabel-variabel melalui pengujian hipotesis, maka penelitian tersebut tidak lagi dinamakan penelitian deskriptif melainkan penelitian pengujian hipotesis atau penelitian penjelasan (explanatory research). Dalam penelitian jenis ini, hipotesis yang telah dirumuskan akan di uji untuk mengetahui adanya pengaruh antara variabel-variabel yang hendak diteliti.

Populasi dari penelitian ini adalah karyawan bagian produksi pada PT Dekor Asia Jayakarya yang berjumlah 45 orang.

Teknik pengambilan sampel yang digunakan adalah teknik pengambilan sampel simple random sampling. Menurut Sugiyono (2006:93) teknik pengambilan sampel simple random sampling adalah pengambilan sampel dari anggota populasi, yang dilakukan secara acak tanpa memperhatikan strata yang ada dalam populasi itu. Jumlah sampel yang diambil dalam penelitian ini dibulatkan sebanyak 31 orang karyawan di bagian produksi PT Dekor Asia Jayakarya.

Analisis data kuantitatif dilakukan dengan menerapkan data-data yang diperoleh kedalam formulasi yang digunakan untuk mengetahui besarnya pengaruh absensi dan insentif terhadap produktivitas kerja karyawan bagian produksi pada PT Dekor Asia Jayakarya.

Analisis kuantitatif dilakukan berdasarkan data primer yang diperoleh melalui 
penyebara daftar pertanyaan kepada karyawan. Daftar pertanyaan yang digunakan yang telah di uji tingkat validitas dan reliabilitasnya.

Pengujian hipotesis, yaitu menguji ada tidaknya korelasi antara variable independen yaitu Tingkat Absensi (X1) dan Insentif (X2) dengan variable dependen yaitu Produktivitas Kerja (Y) karyawan bagian produksi pada PT Dekor Asia Jayakarya. Oleh sebab itu untuk memudahkan perhitungan dan lebih akurat maka dilakukan perhitungan dengan SPSS for windows.

Regresi Linier berganda digunakan untuk mengetahui pengaruh Tingkat Absensi (X1) dan Insentif (X2) dengan variable dependen yaitu Produktivitas Kerja (Y). Untuk mengetahui pengaruh Tingkat Absensi (X1) dan Insentif (X2) terhadpa Produktivitas Kerja (Y) dilakukan perhitungan dengan analisis regresi linier berganda dengan rumus : $\mathrm{Y}=\mathrm{a}+\mathrm{b}_{1} \mathrm{X}_{1}+$ $\mathrm{b}_{2} \mathrm{X}_{2}$

Dimana:

$\mathrm{Y}=$ tingkat prestasi kerja

a $\quad=$ konstanta

$\mathrm{b}_{1}, \mathrm{~b}_{2}=$ koefisien regresi

$\mathrm{X}_{1} \quad=$ variable absensi

$\mathrm{X}_{2} \quad=$ variable insentif

Selain itu dilakukan analisis deskriptif kualitatif berdasarkan data yang diperoleh dari kuesioner.

\section{DATA, ANALISIS DAN PEMBAHASAN}

Dalam menjalankan aktivitas kerjanya, PT Dekor Asia Jayakarya menggunakan sistem absensi dengan menggunakan mesin sidik jari, sehingga data dapat diperoleh secara akurat tanpa ada manipulasi data dari karyawan tersebut. Adapun jumlah karyawan PT Dekor Asia Jayakarya bagian produksi adalah 31 orang.

Produktivitas tenaga kerja dipengaruhi pula oleh tingkat kehadiran karyawan dalam tempat kerja atau absensi karyawan. Produktivitas tidak mungkin tercapai secara optimal jika tingkat kehadiran karyawan sangat rendah, karena karyawn tidak masuk kerja, secara optimal tidak akan menghasilkan produk seperti yang di harapkan.

Analisis regresi linier digunakan untuk mengetahui besarnya pengaruh variable bebas (Tingkat Absensi dan Insentif) terhadap variable terikat (Produktivitas Kerja) pada PT Dekor Asia Jayakarya.

Dari hasil penelitian olah data, hasil analisis deskriptif dalam penelitian ini dapat dilihat pada table berikut :

Tabel 4.6

Deskripsi Statistik

Descriptive Statistics

\begin{tabular}{|l|r|r|r|r|r|}
\hline & N & Minimum & Maximum & Mean & \multicolumn{1}{|c|}{ Std. Deviation } \\
\hline Tingkat Absensi & 31 & 40.00 & 72.00 & 58.7419 & 7.98318 \\
Insentif & 31 & 36.00 & 71.00 & 58.1613 & 9.12176 \\
Produktivitas Kerja & 31 & 44.00 & 73.00 & 60.4516 & 7.15932 \\
Valid N (listwise) & 31 & & & & \\
\hline
\end{tabular}

Dari tabel 4.6 variabel Tingkat Absensi (X1) nampak bahwa jumlah $\mathrm{N}$ sebanyak 31 responden atau $\mathrm{N}=31$ orang dari jumlah tersebut nilai rata-rata Mean sebesar 58,74 simbangan baku atau Std. Deviation 7,983, nilai miminal atau minimum 40, dan nilai maksium atau maximum 72 hal ini dapat dikatakan bahwa kualitas Tingkat Absensi karyawan di PT. Dekor Asia Jayakarya berada dalam kategori Tinggi.

Dari tabel 4.6 variabel Insentif (X2) nampak bahwa jumlah $\mathrm{N}$ sebanyak 31 responden atau $\mathrm{N}=31$ orang dari jumlah tersebut nilai rata-rata Mean sebesar 58,16 simbangan baku atau Std. Deviation 9,121, nilai miminal atau minimum 36 , dan nilai maksium atau maximum 71 hal ini dapat dikatakan bahwa kualitas Insentif karyawan di PT. Dekor Asia Jayakarya berada dalam kategori Tinggi.

Dari tabel 4.6 variabel Produktivitas Kerja (Y) nampak bahwa jumlah N sebanyak 31 responden atau $\mathrm{N}=31$ orang dari jumlah tersebut nilai rata-rata Mean sebesar 60,45 simbangan baku atau Std. Deviation 7,159, nilai miminal atau minimum 44 , dan nilai maksium atau maximum 73 hal ini dapat dikatakan bahwa kualitas Produktivitas Kerja karyawan di PT. Dekor Asia Jayakarya berada dalam kategori Tinggi.

Adapun hasil rekap analisis regresi linear berganda adalah sebagai berikut: 
Tabel 4.11

Hasil Uji Regresi Linier Berganda Coefficients $^{\mathrm{a}}$

\begin{tabular}{|c|c|c|c|c|c|c|}
\hline \multirow{2}{*}{\multicolumn{2}{|c|}{ Model }} & \multicolumn{2}{|c|}{ Unstandardized Coefficients } & \multirow{2}{*}{$\begin{array}{l}\text { Standardized } \\
\text { Coefficients } \\
\text { Beta }\end{array}$} & \multirow[b]{2}{*}{$\mathrm{t}$} & \multirow[b]{2}{*}{ Sig. } \\
\hline & & B & Std. Error & & & \\
\hline 1 & (Constant) & 20.349 & 8.290 & & 2.455 & \\
\hline & Tingkat Absensi & .348 & 134 & .388 & 2.593 & \\
\hline & Insentif & .338 & .118 & .430 & 2.874 & \\
\hline
\end{tabular}

Dengan melihat persamaan regresi linear di atas, maka dapat dijelaskan bahwa:

a) Bila tingkat absensi tinggi, maka produktivitas kerja di PT. Dekor Asia Jayakarya akan meningkat.

b) Bila tingkat insentif tinggi, maka produktivitas kerja di PT. Dekor Asia Jayakarya akan meningkat.

Faktor dominan yang mempengaruhi produktivitas kerja di PT. Dekor Asia Jayakarya adalah variabel tingkat absensi, hal ini dapat dilihat dari nilai Standardized Coefficients dari Variabel tingkat absensi sebesar 0,348 lebih tinggi dibandingkan dengan nilai Standardized Coefficients variabel bebas lainnya.

Adapun kriteria yang digunakan untuk melihat linearitas antara variabel Tingkat Absensi dan Insentif terhadap Produktivitas Kerjadi PT. Dekor Asia Jayakarya dengan cara melihat nilai probabilitas ( $p$-value) pada tabel ANOVA berikut:

Tabel 4.12

Hasil Uji Anova

$\mathrm{ANOVA}^{b}$

\begin{tabular}{|l|r|r|r|r|r|}
\hline Model & Sum of Squares & \multicolumn{1}{c|}{ df } & Mean Square & F & \multicolumn{1}{c|}{ Sig. } \\
\hline \hline Regression & 712.965 & 2 & 356.482 & 12.103 & .000 \\
Residual & 824.712 & 28 & 29.454 & & \\
Total & 1537.677 & 30 & & & \\
\hline
\end{tabular}

a. Predictos: (Constant), Insentifi, Tinghat Absensi

b. Dependent Varable: Produdtivitas Keria

Dari hasil perhitungan dengan SPSS terlihat bahwa nilai $\mathrm{F}$ hitung adalah sebesar $12,03$ ( $p$-value $=0)$. Nilai probabilitas ( $p$-value $)$ $=0$ (nol) tersebut lebih kecil dari nilai alpha $(0,05)$. Karena nilai probabilitas ( $p$-value) < alpha maka dapat disimpulkan bahwa variabel Tingkat Absensi dan Insentif terhadap Produktivitas kerja di PT. Dekor Asia Jayakarya bersifat signifikan.
Dari hasil perhitungan dengan menggunakan SPSS diperoleh t hitung sebesar 2,593 dengan probabilitas ( $p$ value) 0,015 . Nilai probabilitas tersebut lebih kecil dari alpa (5\%). Dengan demikian, dapat disimpulkan bahwa Tingkat Absensi berpengaruh terhadap Produktivitas kerjadi PT. Dekor Asia Jayakarya.

Tabel 4.13

Hasil Uji Parsial

\begin{tabular}{|c|c|c|c|c|c|}
\hline & & Coefficients ${ }^{A}$ & & & \\
\hline \multirow[b]{2}{*}{ Model } & \multicolumn{2}{|c|}{ Unstandardized Coefficients } & \multirow{2}{*}{$\begin{array}{c}\begin{array}{c}\text { Standardized } \\
\text { Coefficients }\end{array} \\
\text { Beta }\end{array}$} & \multirow[b]{2}{*}{$t$} & \multirow[b]{2}{*}{ Sig. } \\
\hline & B & Std. Error & & & \\
\hline (Constant) & 20.349 & 8.290 & & 2.455 & .021 \\
\hline Tingkat Absensi & .348 & .134 & .388 & 2.593 & .015 \\
\hline Insentif & .338 & .118 & .430 & 2.874 & .008 \\
\hline
\end{tabular}

a. Dependent Variable: Produktivitas Kerja

Dari hasil perhitungan dengan menggunakan SPSS diperoleh $\mathrm{t}$ hitung sebesar 2,593 dengan probabilitas ( $p$ value) 0,015 . Nilai probabilitas tersebut lebih kecil dari alpa (5\%). Dengan demikian, dapat disimpulkan bahwa Tingkat Absensi berpengaruh terhadap Produktivitas kerjadi PT. Dekor Asia Jayakarya.

Koefisien determinasi atau nilai adjusted $\mathrm{R}^{2}$ adalah pengukuran dari nilai koefisien korelasi (R).

Tabel 4.14

Model Summary

Model Summary

\begin{tabular}{|l|r|r|r|r|}
\hline Model & \multicolumn{1}{|c|}{$R$} & R Square & Adjusted R Square & $\begin{array}{c}\text { Std. Error of the } \\
\text { Estimate }\end{array}$ \\
\hline 1 & $.681^{\mathrm{a}}$ & .464 & .425 & 5.42716 \\
\hline
\end{tabular}

a. Predictors: (Constant), Insentif, Tingkat Absensi

Nilai adjusted $\mathrm{R}^{2}$ yang tersaji pada tabel 4.12 di atas menunjukkan nilai 0,425 atau $42,5 \%$. Hal tersebut bisa diartikan bahwa 42,5\% Produktivitas Kerja karyawan di PT. Dekor Asia Jayakarya dapat jelaskan oleh variabel Tingkat Absensi dan Insentif sedangkan sisanya sebesar $57,5 \%$ dijelaskan oleh variabel-variabel lain di luar variabel Tingkat Absensi dan Insentif. Nilai adjusted $\mathrm{R}^{2}$ dalam penelitian ini cukup tinggi, sehingga bisa dikatakan bahwa Tingkat Absensi dan Insentif berpengaruh erat terhadap Produktivitas kerjadi PT. Dekor Asia Jayakarya. 


\section{KESIMPULAN}

Berdasarkan analisis data yang telah dilakukan, maka penelitian ini menghasilkan kesimpulan sebagai berikut:

1. Variabel Tingkat Absensi berpengaruh terhadap Produktivitas Kerja Karyawan di Pada PT. Dekor Asia Jayakarya dengan nilai probabilitas sebesar 0,015.

2. Variabel Insentif berpengaruh terhadap Produktivitas Kerja Karyawan di Pada PT. Dekor Asia Jayakarya dengan nilai probabilitas sebesar 0,008.

3. Variabel Tingkat Absensi dan Insentif berpengaruh secara simultan terhadap Produktivitas Kerja Karyawan di Pada PT. Dekor Asia Jayakarya dengan koefisien determinasi sebesar $42,5 \%$.

4. Berdasarkan nilai koefisien beta, terlihat bahwa faktor Tingkat Absensi merupakan variabel yang paling dominan berpengaruh terhadap Produktivitas Kerja Karyawan di Pada PT. Dekor Asia Jayakarya.

\section{DAFTAR PUSTAKA}

Arikunto, Suharsimi. 2002. Prosedur Penelitian, Suatu Pendekatan Praktis. Edisi Revisi. Jakarta: Rineka Cipta

Consuelo G. Sevilla...[et.al], 1993. Pengantar Metode Penelitian. VI-Press, Jakarta

Dessler, Gery.1997. Manajemen Sumberdaya Manusia Jilid 2. Diterjemahkan oleh Paramitha Rahayu. Jakarta: PT. Prenhallindo

Gasperz, Vincent, 2000. Manajemen Produktivitas Bisnis Global, terjemahan Gramedia Pustaka Utama, Jakarta

Ghozali, Imam. 2005. Aplikasi Analisis Multivariate dengan program SPSS. Badan. Penerbit Universitas Diponegoro, Semarang

Hadikusuma, 1996. Segi Manusia dalam Organisasi. Jilid Pertama. Jakarta: PT. Pustaka Bina Pustaka
Handoko, Hani. 2003. Manajemen, edisi kedua. Yogyakarta: BPFE UGM

Hariandja, Mariot Tua Effendy. 2002. Manajemen Sumberdaya Manusia. Jakarta: PT. Gramedia Widiasarana Indonesia

Hasan, M. Iqbal. 2002. Manajemen Sumberdaya Manusia. Jakarta: Bumi Aksara

Hasan, M. Iqbal. 2002. Pokok-pokok Metodelogi Penelitian dan Aplikasinya. Jakarta: Bumi Aksara

Hasan, M. Iqbal. 2002. Pokok-pokok Metodelogi Penelitian dan Aplikasinya. Jakarta: Ghalia Indonesia

Hasibuan, Malayu SP. 2002. Manajemen Sumberdaya Manusia. Jakarta: Bumi Aksara

Hasibuan, Malayu. 2008. Manajemen Sumber Daya Manusia Edisi Revisi. Jakarta: Bumi Aksara

Hasley, George D. 1992. Asas-asas Manajemen. Bandung: Alumni

Ichsan, A.1981. Tata Administrasi Karyawan : dasar dasar ilmu administrasi dan penerapan di Indonesia. Jakarta

J. Ravianto. 1985. Produktivitas dan Manajemen. Yogyakarta : UGM Press

Mathis, Robert L. Dan Jackson, John H. 2002. Manajemen Sumberdaya Manusia. Diterjemahkan oleh Diana Angelica. Jakarta: Salemba Empat

Muchdarsyah. Sinungan. (2008). Produktivitas Apa dan Bagaimana. Jakarta : PT Bumi Aksara

Nazir, Mohammad. 1999. Metode Penelitian. Jakarta: Ghalia Indonesia

Nitisemito, Alex. 1982. Manajemen Personalia. Jakarta: Ghalia Indonesia

Nursalam. 2008. Konsep Dan Penerapan Metodologi Penelitian Ilmu Keperawatan, 


\section{JURNAL MANAJEMEN VOL 4 NO.2 DESEMBER 2014}

Edisi 2. Jakarta : Penerbit Salemba Medika

Ranupandojo, dan Husnan. 1993. Manajemen Personalia. Yogyakarta

Sarwoto, 1991. Dasar-dasar Organisasi dan Manajemen. Jakarta: Ghalia Indonesia

Schuler, Randall. S dan Susan E Jackson. 1996. Manajemen Sumberdaya Manusia. Jakarta: Erlangga

Sedarmayanti. (2001). Sumber Daya Manusia dan Produktivitas Kerja. Jakarta : Mandar Maju

Siagian, Sondang P. 2003. Manajemen Sumberdaya Manusia. Jakarta: Bumi Aksara

Siagian, Sondang P. 2003. Teori dan Praktek Kepemimpinan. Jakarta : Rineka Cipta

Singarimbun, Masri dan Effendy, Sofyan. 1995. Metode Penelitian Survey, Edisi Revisi. Jakarta: LP3ES

Sudriamunawar, Haryono. 2006. Kepemimpinan, Peran Serta dan Produktivitas. Bandung : Mandar Maju

Sugiyono. 2006. Metode Penelitian Bisnis. Bandung: CV. Alfabeta 